Article

\title{
Isomorphous Crystals from Diynes and Bromodiynes Involved in Hydrogen and Halogen Bonds
}

\author{
Pierre Baillargeon ${ }^{1, *}$, Édouard Caron-Duval ${ }^{1}$, Émilie Pellerin ${ }^{1}$, Simon Gagné ${ }^{1}$ \\ and Yves L. Dory ${ }^{2, *}$ \\ 1 Département de chimie, Cégep de Sherbrooke, 475 rue du Cégep, Sherbrooke, QC J1E 4K1, Canada; \\ edouard.caron-duval@usherbrooke.ca (E.C.-D.); Emilie.Pellerin@USherbrooke.ca (E.P.); \\ Simon.Gagne2@USherbrooke.ca (S.G.) \\ 2 Laboratoire de synthèse supramoléculaire, Département de chimie, Institut de Pharmacologie, \\ Université de Sherbrooke, 3001 12e avenue nord, Sherbrooke, QC J1H 5N4, Canada \\ * Correspondence: Pierre.Baillargeon@cegepsherbrooke.qc.ca (P.B.); Yves.Dory@usherbrooke.ca (Y.L.D.); \\ Tel.: +1-819-564-6350 (ext. 4114) (P.B.); +1-819-821-8000 (ext. 75299) (Y.L.D.)
}

Academic Editor: Sławomir J. Grabowski

Received: 4 February 2016; Accepted: 24 March 2016; Published: 2 April 2016

\begin{abstract}
Isomorphous crystals of two diacetylene derivatives with carbamate functionality (BocNH- $\mathrm{CH}_{2}$-diyne- $\mathrm{X}$, where $\mathrm{X}=\mathrm{H}$ or $\mathrm{Br}$ ) have been obtained. The main feature of these structures is the original 2D arrangement (as supramolecular sheets or walls) in which the $\mathrm{H}$ bond and halogen bond have a prominent effect on the whole architecture. The two diacetylene compounds harbor neighboring carbamate (Boc protected amine) and conjugated alkyne functionalities. They differ only by the nature of the atom located at the penultimate position of the diyne moiety, either a hydrogen atom or a bromine atom. Both of them adopt very similar 2D wall organizations with antiparallel carbamates (as in antiparallel beta pleated sheets). Additional weak interactions inside the same walls between molecular bricks are $\mathrm{H}$ bond interactions (diyne- $\mathrm{H} \cdots \mathrm{O}=\mathrm{C}$ ) or halogen bond interactions (diyne- $\mathrm{Br} \cdots \mathrm{O}=\mathrm{C}$ ), respectively. Based on crystallographic atom coordinates, DFT $(B 3 L Y P / 6-31++G(d, p))$ and DFT $(M 06-2 X / 6-31++G(d, p))$ calculations were performed on these isostructural crystals to gain insight into the intermolecular interactions.
\end{abstract}

Keywords: isomorphism; crystal structures; supramolecular sheets; hydrogen bond; halogen bond; synthesis; diacetylene; bromodiyne; terminal alkyne; DFT theoretical calculation

\section{Introduction}

One of the important scientific issues today involves the development of materials with controlled hierarchical structures organized in different sizes, especially at the nanoscopic scale [1]. Scientists exploit supramolecular chemistry (bottom-up strategy) to achieve this goal and control the organization of molecules into diverse 1D [2-4], 2D [5-9] or 3D shapes [10-12]. Owing to their directional potential, hydrogen bond [13-23] or halogen bond [24-36] are intermolecular forces that are often used to stick molecular building blocks together. Recently, in our laboratories, we exploited mainly $\mathrm{H}$ bonds to build supramolecular walls based on lactams [37] or proline derivatives [38].

Since isostructurality (isomorphism) is a successful approach adopted in the construction of organic assemblies [39-42], we decided to investigate if hydrogen bonds and halogen bonds could be used with similar results. We now present 2D layered isostructural crystals of two diacetylene derivatives (Figure 1) that are stabilized with hydrogen or halogen bonds. One of the main interests of these crystals is that they differ only by a diyne $\mathrm{C}-\mathrm{H} \cdots \mathrm{O}=\mathrm{C}$ or $\mathrm{C}-\mathrm{Br} \cdots \mathrm{O}=\mathrm{C}$ interaction. For this reason, it became very easy to isolate and compare these geometric arrangements since their environments are identical. The hydrogen bonds could be compared to the isosteric halogen bonds using DFT 
calculations based on X-ray atomic coordinates. Better knowledge of the behavior of these interactions could bring additional tools in crystal engineering and in material design, as well as for efficient and fruitful drug design. Indeed, terminal alkynes [43,44] and haloalkynes [45-47] are biologically important classes of molecules.

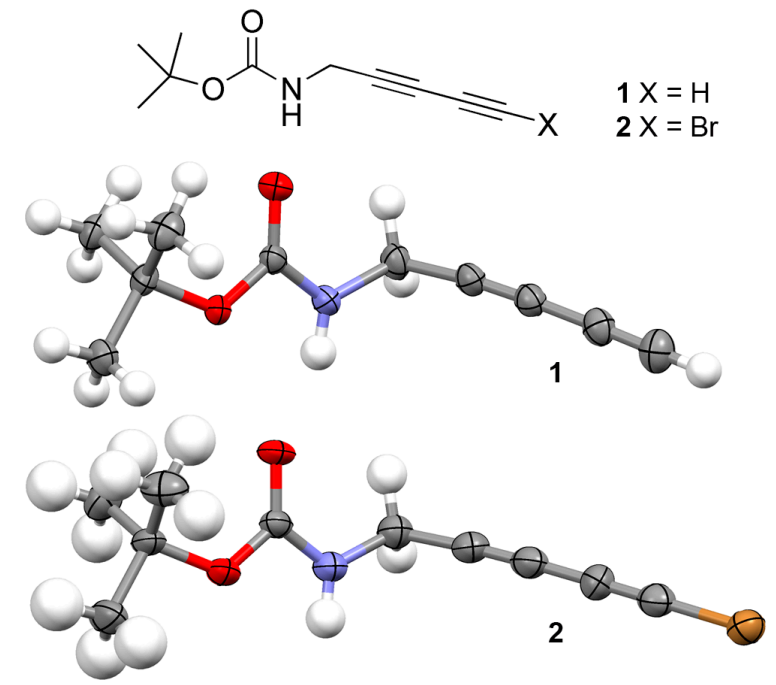

Figure 1. Chemical and crystal (ORTEP) structures of the diacetylene derivatives $1\left(\mathrm{BocNHCH}_{2}\right.$ $\mathrm{CCCCH})$ and 2 (BocNHCH$\left.{ }_{2} \mathrm{CCCCBr}\right)$.

\section{Results and Discussion}

\subsection{Synthesis}

Both isosteric compounds $\mathbf{1}$ and $\mathbf{2}$ were obtained in a straightforward and efficient manner from commercially available $N$-Boc-propargylamine 3 and ethynyltrimethyl silane 4 (Scheme 1). These two reactants were coupled together with Hay catalyst [48] to yield the diyne 5 with a yield of 55\%, easily separated from two symmetrical reaction byproducts 6 and 7. The trimethyl silyl group of 5 was either cleaved with potassium carbonate to give the first target diyne $\mathbf{1}$ (60\% yield) or it was replaced by a bromine atom to afford the other desired compound 2 with a yield of $30 \%$. This was achieved with $\mathrm{N}$-bromosuccinimide (NBS) in the presence of silver nitrate. In the process, some diyne $\mathbf{1}$ was also obtained (14\%).

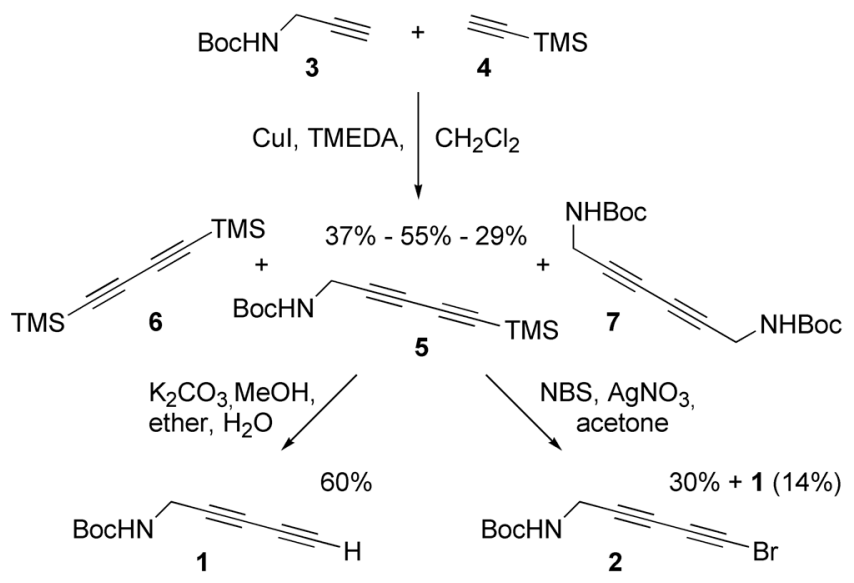

Scheme 1. Synthesis of diynes 1 and 2. 


\subsection{Crystallographic Studies}

Crystals of both diynes $\mathbf{1}$ and $\mathbf{2}$ are isostructural. Their unit cells are very similar, being slightly larger for bromide $\mathbf{2}$ (Table 1). The replacement of a hydrogen atom in $\mathbf{1}$ by a bromine atom in $\mathbf{2}$ leads to an increase in density. The $a b$ planes of the crystal structures (Figure 2) are constituted of molecular walls whose bricks are maintained by weak forces like hydrogen bonds (alkyne 1, Figure 2a) or a combination of hydrogen bonds and halogen bonds (bromoalkyne 2, Figure 2b). For both crystals, the carbamates stack on top of each other along the $b$-axis and in an antiparallel way through $\mathrm{NH} \cdots \mathrm{OC}$ hydrogen bonds (the NH... OC hydrogen bond distances are very similar, being $2.054 \AA$ and 2.088 $\AA$ for $\mathbf{1}$ and 2, respectively). Consequently, the rigid diyne arms stick out from each side of the 1D carbamate tapes in an alternate manner. Their constitutive atoms also lay almost in the same $a b$ plane. As an additional proof of isostericity, the $b$ side of both unit cells displays almost identical length $(b=9.3135 \AA$ for $\mathbf{1}$ and $b=9.2090 \AA$ for 2$)$.

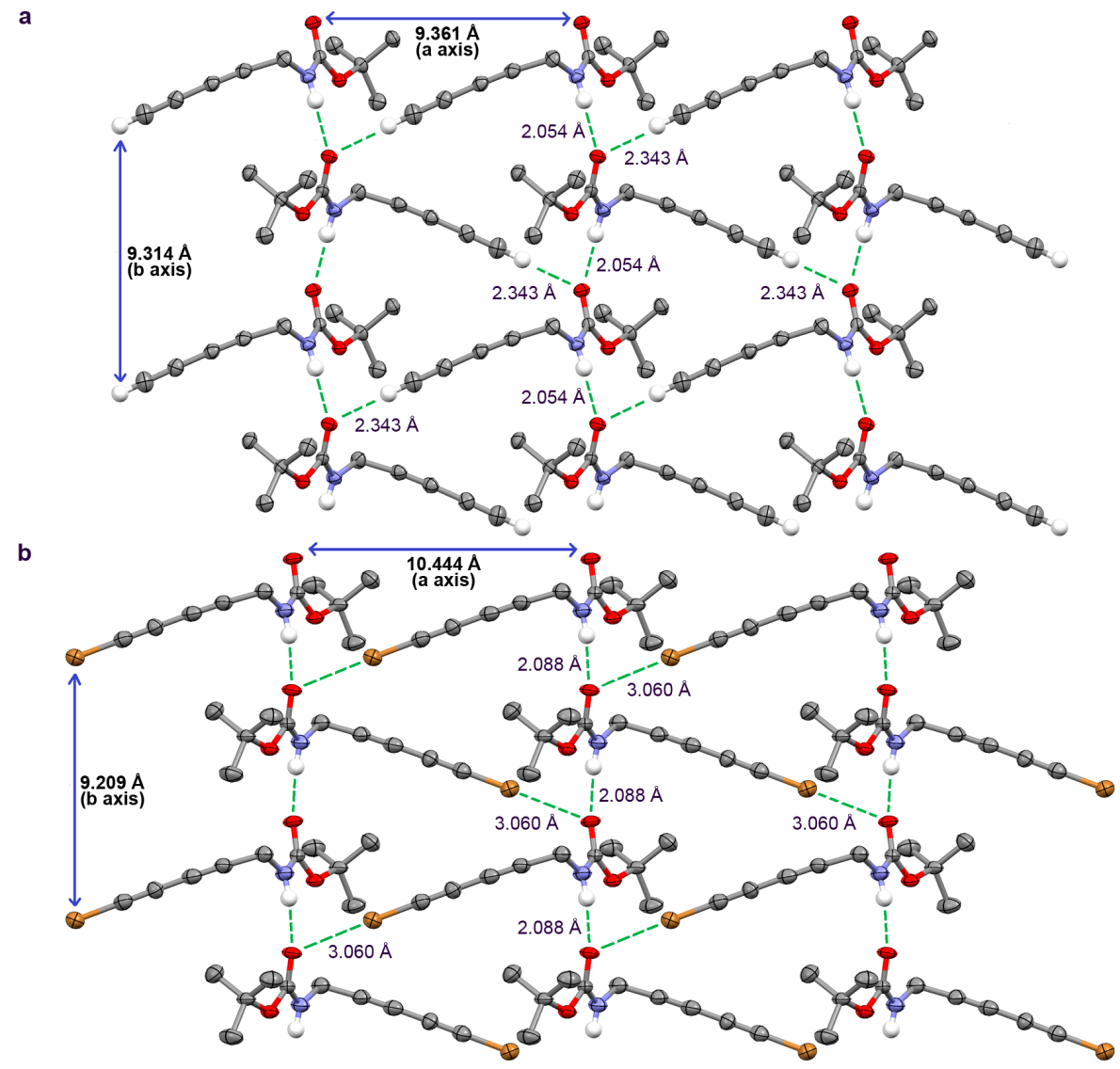

Figure 2. Halogen and/or hydrogen bonds inside the supramolecular walls of (a) diyne $\mathbf{1}$ and (b) bromodiyne 2 . The non polar hydrogen atoms have been removed for clarity.

Looking along the $b$-axis (Figure 3, top views of the supramolecular walls), there is no significant difference either. The repetitive unit along the $c$-axis is just a little bit longer in $2(c=12.274 \AA)$ by comparison with $\mathbf{1}(c=11.898 \AA)$. All walls have opposite carbonyl orientation. The main difference between crystals 1 and 2 may be seen along the $a$-axis. It is a direct consequence of the replacement of an $\mathrm{H}$ atom by a Br atom. The C-Br bond being longer $(1.800 \AA)$ than the C-H bond $(0.951 \AA)$ leads to longer a side for the unit cell in $\mathbf{2}(a=10.4435 \AA)$ by comparison with $\mathbf{1}(a=9.3613 \AA)$. The elongation effect arises also from major differences existing between the non-conventional $\mathrm{C}-\mathrm{H} \cdots \mathrm{O}=\mathrm{C}$ hydrogen bond [49] length $(2.343 \AA)$ and the $\mathrm{C}-\mathrm{Br} \cdots \mathrm{O}=\mathrm{C}$ halogen bond length $(3.060 \AA)$. In fact, this latter distance is $9 \%$ shorter than the sum of the van der Waals radii of $\mathrm{Br}$ and $\mathrm{O}$ [50-52], strongly suggesting 
that there is more at stake than a simple van der Waals contact between the two heteroatoms. This is also supported by the alignment of the four atoms $\mathrm{C}-\mathrm{Br} \cdots \mathrm{O}=\mathrm{C}$ matching that of the $\mathrm{C}-\mathrm{H} \cdots \mathrm{O}=\mathrm{C}$ atoms involved in a hydrogen bond [53]. Few examples of such halogen bonds are reported in the Cambridge Structural Database [26,54-56].

Table 1. Crystallographic data for diynes 1 and 2.

\begin{tabular}{ccc}
\hline & Diyne 1 & Diyne 2 \\
\hline formula & $\mathrm{C}_{10} \mathrm{H}_{13} \mathrm{NO}_{2}$ & $\mathrm{C}_{10} \mathrm{H}_{12} \mathrm{BrNO}_{2}$ \\
$\mathrm{MW} / \mathrm{g} \cdot \mathrm{mol}^{-1}$ & 179.21 & 258.12 \\
crystal system & monoclinic & monoclinic \\
space group & $\mathrm{P} 21 / \mathrm{c}$ & $\mathrm{P} 21 / \mathrm{c}$ \\
$a / \AA$ & $9.3613(15)$ & $10.4435(16)$ \\
$b / \AA$ & $9.3135(14)$ & $9.2090(15)$ \\
$c / \AA$ & $11.8981(19)$ & $12.2744(19)$ \\
$\beta / \mathrm{deg}$ & $102.497(5)$ & $102.599(4)$ \\
$V / \AA \AA^{3}$ & $1012.8(3)$ & $1152.1(3)$ \\
$Z$ & 4 & 4 \\
$\rho_{\text {calc }} / \mathrm{g} \cdot \mathrm{cm}$ & 1.175 & 1.488 \\
meas. reflns & 5204 & 16523 \\
ind. reflns & 1848 & 2175 \\
$R_{\text {int }}$ & 0.0403 & 0.0656 \\
$R_{1}[I>2 \sigma(\mathrm{I})]$ & 0.0382 & 0.0644 \\
$w R_{2}[I>2 \sigma(\mathrm{I})]$ & 0.0840 & 0.1662 \\
GoF & 1.027 & 1.133 \\
\hline
\end{tabular}

a

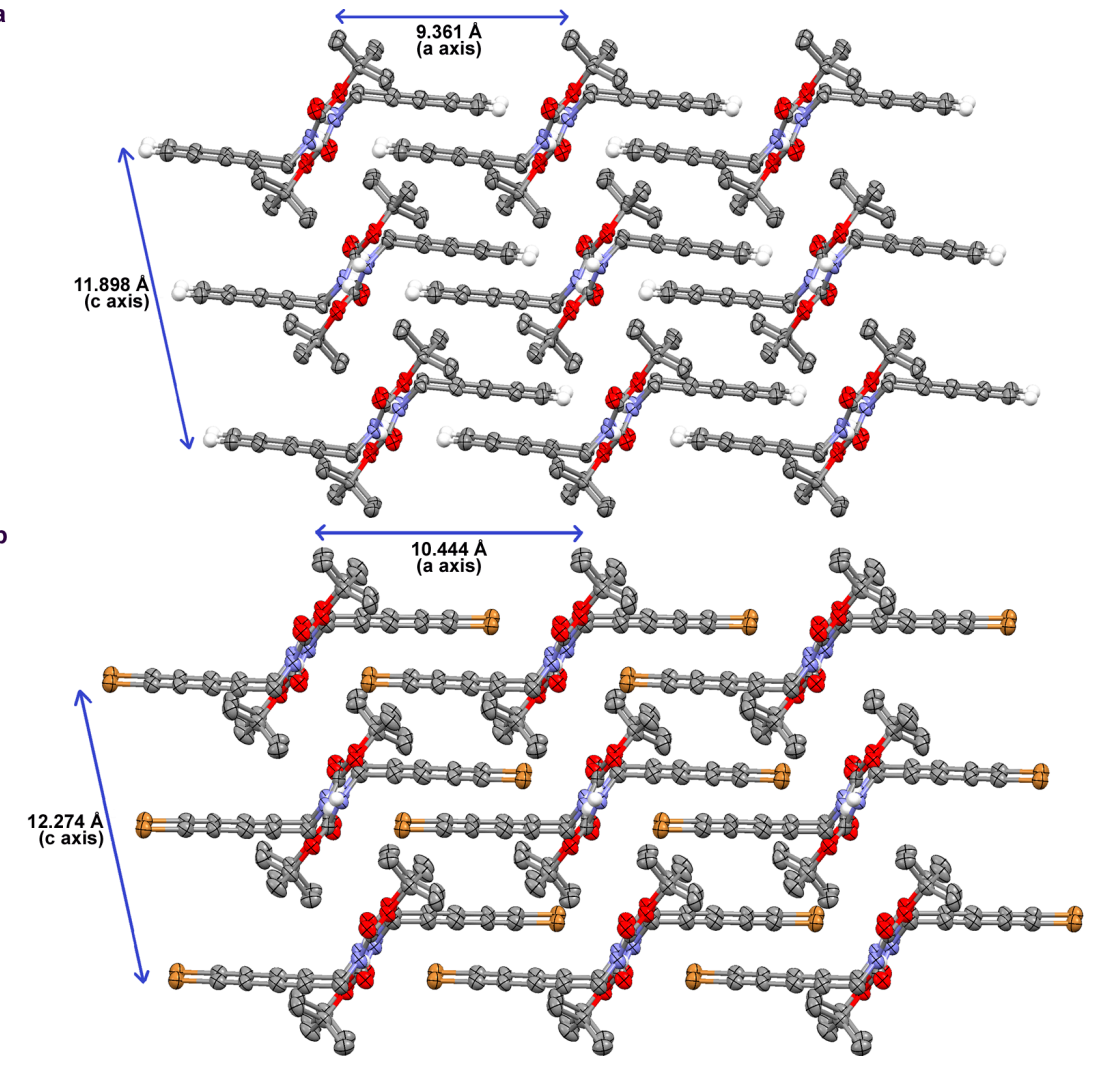

Figure 3. Top views of the supramolecular walls, seen along the $b$-axis of (a) diyne $\mathbf{1}$ and (b) bromodiyne 2 . The non polar hydrogen atoms have been removed for clarity. 
Finally, for both crystals, slow degradation occurs over time at room temperature and in ambient atmosphere. At this moment, it this difficult to conclude what the "degradation" products might be. Although single-crystal-to-single-crystal dimerization has been observed in other bromodiacetylene derivatives, this process is very unlikely in the case of $\mathbf{1}$ and 2 [57]. Indeed, their geometric arrangements are inappropriate for this type of reaction. The diyne systems are parallel as requested; nevertheless, the angle of the reactive carbons and mostly their distance separations are not favorable, being distorted and much too long, respectively (Figure 4). Topochemical polymerization of diacetylene is also prevented because there is no long range parallel stacking of diynes [58-67].

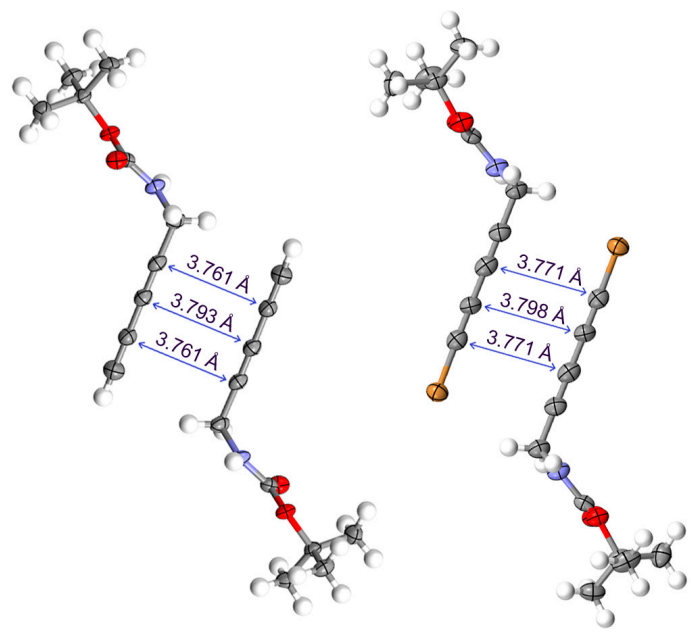

Figure 4. Geometrical characteristics of the closest parallel diyne rods in crystals of $\mathbf{1}$ and 2.

\subsection{Computational Studies}

In order to gain more insight into the energetics at stake in the crystals of $\mathbf{1}$ and $\mathbf{2}$, a DFT study was carried out on simplified models 8-8-9 and 8-8-10 of these crystals (Figure 5) [68-71].

a

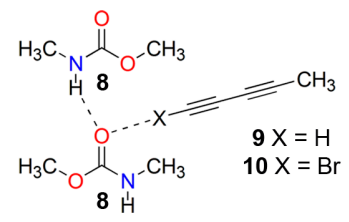

b
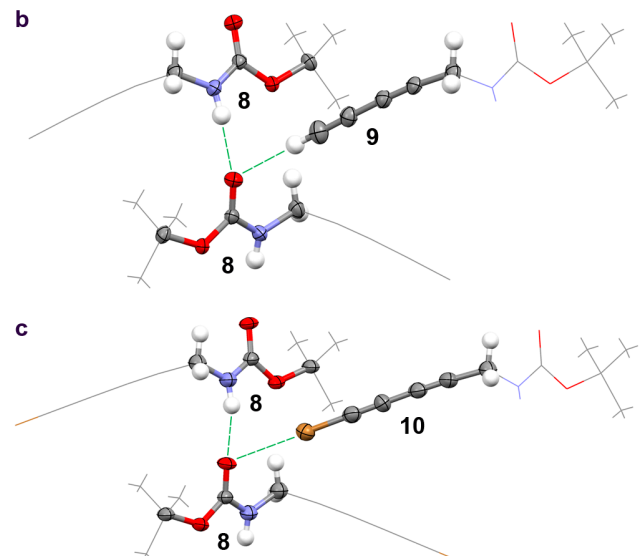

Figure 5. Summary of DFT calculations. (a) structures of systems 8-8-9 and 8-8-10, in which 8, 9 and 10 are $\mathrm{N}, \mathrm{O}$-dimethylcarbamate, penta-1,3-diyne and 1-bromopenta-1,3-diyne. Initial geometries for systems (b) 8-8-9 extracted from the crystal of 1 and (c) 8-8-10 corresponding to the crystal of 2 . 
Thus, both starting geometries are constituted of two N,O-dimethylcarbamate molecules 8 , interacting with each other through a hydrogen bond. In each case, the carbamate carbonyl oxygen already involved in the hydrogen bond is also bound, via a bifurcated non-covalent bond [72], to the terminal atom of a simple diyne, either penta-1,3-diyne $\mathbf{9}$ (extracted from crystal of $\mathbf{1}$ ) or 1-bromopenta-1,3-diyne $\mathbf{1 0}$ (extracted from crystal of 2). This apparent oversimplification is justified by our desire to "isolate" the energy stored in the hydrogen and halogen bonds present in these crystals. Therefore, all atoms purely involved in these weak interactions were retained while the others were discarded. Without the crystal lattice constraint, calculations could obviously yield extremely different final structures, especially in the current cases. Indeed, the potential energy surface (PES) involving weak interactions is known to be shallow [73]. This means that important geometrical variations of distances and angles between $\mathrm{H}$-bond and halogen bond partners may result in minute energy changes (e.g., $<0.2 \mathrm{kcal} \cdot \mathrm{mol}^{-1}$ ). Nevertheless, it is still possible to gauge if the systems 8-8-9 and 8-8-10 are near a minimum on the PES by not being too stringent on the first derivative (maximum energy gradient) requirements during calculations.

Two DFT methods were applied to study these systems, namely the widely used B3LYP functional as well as the M06-2X method known to be more suitable to treat weak interactions and peptides [74,75]. The B3LYP minimizations led to RMSDs as small as $0.16 \AA$ and $0.34 \AA$ for the 8-8-9 and 8-8-10 systems, respectively. The RMSD figures were similar for the M06-2X method: $0.39 \AA$ and $0.37 \AA$ for the same systems (Figure 6). The distances between weak interaction partners (excluding van der Waals) remain close before and after calculations (distance $\mathrm{CO} \times \times \times \mathrm{HN}$ of $2.93 \AA$, 3.03-3.02 $\AA, 2.98-2.95 \AA$ in crystals 1 and 2, B3LYP, M06-2X DFT calculations, respectively; distance CO $\times \times \times$ HCCCC of $3.29 \AA, 3.34 \AA$, $3.22 \AA$ in crystal 1, B3LYP, M06-2X DFT calculations, respectively; distance C $\underline{\mathrm{O}} \times \times \times$ BrCCCC of $3.06 \AA$, $3.10 \AA, 2.95 \AA$ in crystal 2, B3LYP, M06-2X DFT calculations, respectively). With these good matches between initial and equilibrium structures [76], it was then possible to convincingly evaluate, or at least rank, the strength of the weak hydrogen and halogen bonding interactions, partially responsible for the orientations of the monomers $\mathbf{1}$ and $\mathbf{2}$ in their respective crystals (Table 2).
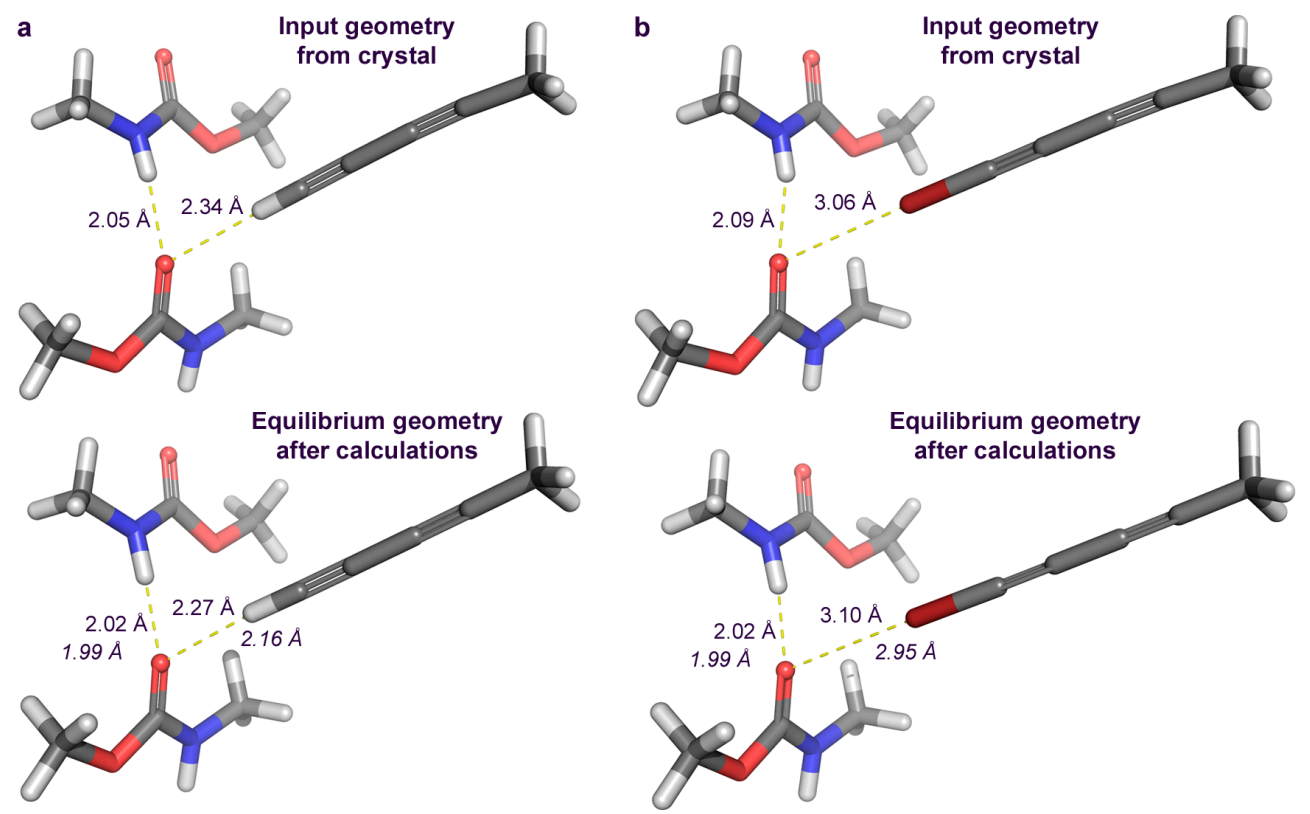

Figure 6. Starting (crystal) and equilibrium (DFT minimization) geometries for (a) system 8-8-9 and for (b) system 8-8-10. Plain figures in the equilibrium geometries are for B3LYP calculations and italic figures for M06-2X calculations. 
Table 2. DFT energies for the minimized geometries.

\begin{tabular}{ccc}
\hline System & \multicolumn{2}{c}{ Energy $\left(E_{\mathbf{h}}\right)^{\mathbf{1}}$} \\
\hline & B3LYP & M06-2X \\
$\mathbf{8}$ & -323.59792 & -323.62775 \\
$\mathbf{9}$ & -192.70191 & -192.73108 \\
$\mathbf{1 0}$ & -2765.83708 & -2766.01159 \\
$\mathbf{8 - 8}$ & -647.20438 & -647.26691 \\
$\mathbf{8 - 8 - 9}$ & -839.90921 & -840.00619 \\
$\mathbf{8 - 8 - 1 0}$ & -3413.04394 & -3413.28685 \\
\hline${ }^{1} E_{\mathrm{h}}$ means Hartree $\left(1 E_{\mathrm{h}}=627.5 \mathrm{kcal} \cdot \mathrm{mol}^{-1}\right)$.
\end{tabular}

Examination of the energy figures obtained after DFT minimization shows that hydrogen or halogen bonds are consistently much weaker following the B3LYP method, in comparison with the M06-2X protocol. For example, B3LYP DFT minimizations yield an energy of $-5.36 \mathrm{kcal} \cdot \mathrm{mol}^{-1}$ for the hydrogen bond between carbamate $\mathrm{NH}$ (donor) and carbamate $\underline{\mathrm{C}} \underline{\mathrm{O}}$ (acceptor) as shown in Figure 6 (E_8-8 - $2 \times$ E_8, meaning Energy of system 8-8 minus twice the Energy of 8 as reported in Table 2). At the M06-2X level, the same hydrogen bond is even stronger with an energy of $-7.16 \mathrm{kcal} \cdot \mathrm{mol}^{-1}$. The corresponding input coordinates of 8-8 (before its minimization) had been obtained from the minimized full systems 8-8-9 and 8-8-10. It was finally possible to estimate the strength of the hydrogen bond between the alkyne hydrogen and the carbamate carbonyl by deducting the energies of system 8-8 and free diyne 9 to the energy of 8-8-9 (E_8-8-9 - E_8-8 - E_9). The strength of the halogen bond between the carbamate $\mathrm{CO}$ of $\mathbf{8}$ and the terminal bromine atom from bromodiyne $\mathbf{1 0}$ was evaluated in the same way (E_8-8-10 - E_8-8 - E_10).

Amazingly, both weak interactions involving alkyne hydrogen and alkyne bromine with a carbamate $\mathrm{CO}$ are very much comparable (same energy range), being weaker than a conventional hydrogen bond between carbamates. These hydrogen and halogen bonds have respective energies of $-1.83 \mathrm{kcal} \cdot \mathrm{mol}^{-1}$ and $-1.56 \mathrm{kcal} \cdot \mathrm{mol}^{-1}$ at the B3LYP DFT level and $-5.15 \mathrm{kcal} \cdot \mathrm{mol}^{-1}$ and $-5.24 \mathrm{kcal} \cdot \mathrm{mol}^{-1}$ following the M06-2X DFT method.

\section{Experimental Section}

\subsection{Synthesis}

Diynes 5-6-7. To a solution of $\mathrm{N}$-Boc-propargylamine $3(1.0 \mathrm{~g}, 6.45 \mathrm{mmol})$ and ethynyltri methylsilane $4(1.78 \mathrm{~mL}, 12.5 \mathrm{mmol})$ in DCM $(50 \mathrm{~mL})$ was added Hay catalyst [freshly prepared by stirring CuI (1.3 g, $6.8 \mathrm{mmol})$ and TMEDA $(1.92 \mathrm{~mL}, 12.9 \mathrm{mmol})$ in DCM (10 mL) under argon]. The reaction mixture was stirred under oxygen atmosphere (balloon) for $110 \mathrm{~min}$. The resulting deep brown residue was purified by flash chromatography (DCM, then ether:hexane 50:50, then ether), yielding the diyne 5 as a brown-orange oil $(887 \mathrm{mg}, 55 \%)$, the diyne 6 as a white solid (458 $\mathrm{mg}, 37 \%$ ) and the diyne 7 as a white solid ( $290 \mathrm{mg}, 29 \%)$.

For diyne 5: $\mathrm{Rf}=0.42$ (hexane:EtOAc, 75:25). ${ }^{1} \mathrm{H}$ NMR $\left(400 \mathrm{MHz}, \mathrm{CDCl}_{3}, \delta \mathrm{ppm}\right): 4.70$ (br s, 1H), 4.00 (br s, 2H), $1.44(\mathrm{~s}, 9 \mathrm{H}), 0.18(\mathrm{~s}, 9 \mathrm{H})$. HRMS $(\mathrm{m} / \mathrm{z})$ calcd for $\mathrm{C}_{13} \mathrm{H}_{21} \mathrm{NO}_{2} \mathrm{SiNa}\left[\mathrm{MNa}^{+}\right]:$274.1234, found: 274.1240 .

For diyne 6: ${ }^{1} \mathrm{H}$ NMR $\left(400 \mathrm{MHz}, \mathrm{CDCl}_{3}, \delta \mathrm{ppm}\right): 0.00(\mathrm{~s}, 18 \mathrm{H})$.

For diyne 7: ${ }^{1} \mathrm{H}$ NMR $\left(400 \mathrm{MHz}, \mathrm{CDCl}_{3}, \delta \mathrm{ppm}\right): 4.91(\mathrm{br}, 1 \mathrm{H}), 3.96(\mathrm{br}, 2 \mathrm{H}), 1.42(\mathrm{~s}, 18 \mathrm{H})$.

Diyne 1. A mixture of diyne 5 ( $208 \mathrm{mg}, 0.83 \mathrm{mmol})$ and $\mathrm{K}_{2} \mathrm{CO}_{3}(508 \mathrm{mg}, 3.68 \mathrm{mmol})$ in $\mathrm{MeOH}$ $(5 \mathrm{~mL})$ and $\mathrm{Et}_{2} \mathrm{O}(5 \mathrm{~mL})$ with a drop of water was stirred at room temperature for $70 \mathrm{~min}$. The solvent was removed under reduced pressure and the residue was purified by chromatography (hexane: $\left.\mathrm{Et}_{2} \mathrm{O}, 70: 30\right)$ to yield the diyne 1 as white crystals $(89 \mathrm{mg}, 60 \%$ ). $\mathrm{Rf}=0.40$ (hexane:EtOAc, 75:25). ${ }^{1} \mathrm{H}$ NMR (300 MHz, CDCl 3 $\delta$ ppm): 4.72 (br s, 1H), 3.99 (br s, 2H), 2.10 (s, 1H), 1.45 (s, 9H). ${ }^{13} \mathrm{C}$ NMR 
(100 MHz, $\left.\mathrm{CDCl}_{3}, \delta \mathrm{ppm}\right): 155.32,80.58,73.25,67.81,67.55,67.33,31.07,28.53$. HRMS $(\mathrm{m} / \mathrm{z})$ calcd for $\mathrm{C}_{10} \mathrm{H}_{13} \mathrm{NO}_{2} \mathrm{Na}\left[\mathrm{MNa}^{+}\right.$]: 202.0839, found: 202.0839 .

Diyne 2. $\mathrm{AgNO}_{3}(36 \mathrm{mg}, 0.21 \mathrm{mmol})$ and NBS (228 mg, $\left.1.28 \mathrm{mmol}\right)$ were added to a solution of diyne $5(270 \mathrm{mg}, 1.07 \mathrm{mmol})$ in acetone $(10 \mathrm{~mL})$ at room temperature. The resulting mixture was stirred for $18 \mathrm{~h}$ under $\mathrm{N}_{2}$ in the absence of light. Purification of the crude product by flash chromatography on silica gel eluting with mixtures of EtOAc and hexane (gradient from 10:90 to 25: 75) provided the title compound $\mathbf{2}$ as an orange solid $(82 \mathrm{mg}, 30 \%)$ and the diyne $\mathbf{1}$ as a white solid $(26 \mathrm{mg}, 14 \%)$. Rf $=0.52$ (hexane:EtOAc, 70:30). ${ }^{1} \mathrm{H}$ NMR (400MHz, $\mathrm{CDCl}_{3}, \delta \mathrm{ppm}$ ): 4.72 (br s,1H), 3.98 (br s, 2H), $1.44(\mathrm{~s}, 9 \mathrm{H})$. ${ }^{13} \mathrm{C} \mathrm{NMR}\left(100 \mathrm{MHz}, \mathrm{CDCl}_{3}, \delta \mathrm{ppm}\right): 155.31,80.58,72.03,68.26,65.15,40.49,31.11,28.53$. HRMS $(\mathrm{m} / \mathrm{z})$ calcd for $\mathrm{C}_{10} \mathrm{H}_{12} \mathrm{BrNO}_{2} \mathrm{Na}\left[\mathrm{MNa}^{+}\right.$]: 279.9944 , found: 279.9951

\subsection{Crystallizations}

Diyne 1 crystallized from a solution of acetone and $\mathrm{CDCl}_{3}$ that was left to stand in a small vial at room temperature for several days. Colorless crystals of $\mathrm{BocNHCH}_{2} \mathrm{CCCCH}, \mathbf{1}$, suitable for X-ray analysis were obtained. A Needle-like specimen of $\mathrm{C}_{10} \mathrm{H}_{13} \mathrm{NO}_{2}(0.05 \mathrm{~mm} \times 0.10 \mathrm{~mm} \times 0.28 \mathrm{~mm})$, was used for the X-ray crystallographic analysis.

The same technique was used to obtain colorless crystals of $\mathrm{BocNHCH}_{2} \mathrm{CCCCBr}, \mathbf{2}$, from a solution of ether, $\mathrm{CDCl}_{3}$ and hexane. A prism-like specimen of $\mathrm{C}_{10} \mathrm{H}_{12} \mathrm{BrNO}_{2}(0.08 \mathrm{~mm} \times 0.15 \mathrm{~mm} \times 0.68 \mathrm{~mm})$, was cropped for the $\mathrm{X}$-ray crystallographic analysis.

\subsection{X-Ray Crystallography}

The X-ray intensity data were measured on a Bruker Apex DUO system equipped with a $\mathrm{Cu}$ K $\alpha$ ImuS micro-focus source with MX optics (Bruker, Madison, WI, USA) $(\lambda=1.54178 \AA$ ). The frames were integrated with the Bruker SAINT software package (Bruker, Madison, WI, USA) using a wide-frame algorithm. Data were corrected for absorption effects using the multi-scan method (SADABS). The structure was solved and refined using the Bruker SHELXTL Software Package (Bruker, Madison, WI, USA), using the space group P 21/c, with $Z=4$ for the formula unit. Full details of the crystallographic data and refinement are presented in Table 1 and in the supporting information file (PDF). CCDC 1451745-1451746 contain the supplementary crystallographic data for this paper. These data can be obtained free of charge via http:/ / www.ccdc.cam.ac.uk/conts/retrieving.html (or from the CCDC, 12 Union Road, Cambridge CB2 1EZ, UK; Fax: +44 1223 336033; E-mail: deposit@ccdc.cam.ac.uk).

\subsection{Computational Details}

All calculations were performed with the GAMESS program package (Iowa State University, Ames, IA, USA) [77] using the B3LYP/6-31++G(dp) and the M06-2X/6-31++G(d,p) density functional basis sets $[78,79]$. No zero point corrections were applied to the calculated raw energies following minimizations. The initial geometries were extracted from the single-crystal X-ray diffraction data (Figure 5). All atoms not directly involved in the hydrogen and halogen bonds were removed and hydrogen atoms were finally added to fill up the valence requirements. For the minimizations, the requested maximum energy gradient was $0.0005 E_{\mathrm{h}} \cdot \mathrm{a}_{0}{ }^{-1}(\mathrm{OPTTOL}=0.0005)$.

\section{Conclusions}

Despite their obvious differences in nature, both hydrogen and halogen bonds [80], between terminal diyne hydrogen or bromine atoms, respectively, with carbonyl oxygen as a partner, behave in the same way geometrically as well as energetically. Consequently, the data gathered in this work suggest that these non-covalent bonds can be used to produce identical patterns in crystals, the only noticeable difference arising from the van der Waals radii of hydrogen and bromine atoms. 
Supplementary Materials: The following are available online at http://www.mdpi.com/2073-4352/6/4/37/s1. Spectral characterization data for compounds 1, 2, 5, 6 and 7 (PDF). RMSD parameters of DFT $x, y$, and $z$ coordinates for systems 8-8-9 and 8-8-10. Crystallographic information files for compounds 1 and 2 (CIF).

Acknowledgments: Financial support by NSERC Canada, the Fonds de recherche du Québec-Nature et technologies (FRQNT, Grant No. 2016-CO-194882), the Programme de Collaboration Universités-Collèges (Grant No. PCUC-9004, Université de Sherbrooke) and the Centre d'étude et de recherche transdisciplinaire étudiants-enseignants (CERTEE, Cégep de Sherbrooke) are gratefully acknowledged, as well as Calcul Québec for computational resources. Many thanks to Tarik Rahem and Victor Fan for their valuable help with the synthesis of diynes 1 and 2 .

Author Contributions: Pierre Baillargeon conceived and designed the experiments; Édouard Caron-Duval, Émilie Pellerin and Simon Gagné performed the experiments; Yves L. Dory carried out the calculations; Pierre Baillargeon and Yves L. Dory analyzed the data; Pierre Baillargeon and Yves L. Dory contributed reagents/materials/analysis tools; Pierre Baillargeon and Yves L. Dory wrote the paper.

Conflicts of Interest: The authors declare no conflict of interest.

\section{Abbreviations}

The following abbreviations are used in this manuscript:

$\begin{array}{ll}\text { NBS } & \text { N-BromoSuccinimide } \\ \text { DFT } & \text { Density-Functional Theory } \\ \text { DCM } & \text { DiChloroMethane } \\ \text { TMEDA } & \text { TetraMethylEthyleneDiAmine } \\ \text { Rf } & \text { Retardation Factor } \\ \text { IR } & \text { InfraRed } \\ \text { NMR } & \text { Nuclear Magnetic Resonance } \\ \text { HRMS } & \text { High-Resolution Mass Spectrometry } \\ \text { GAMESS } & \text { General Atomic and Molecular Electronic Structure System }\end{array}$

\section{References}

1. Rao, C.N.R.; Cheetham, A.K. Science and technology of nanomaterials: Current status and future prospects. J. Mater. Chem. 2001, 11, 2887-2894. [CrossRef]

2. Gauthier, D.; Baillargeon, P.; Drouin, M.; Dory, Y.L. Self-Assembly of Cyclic Peptides into Nanotubes and Then into Highly Anisotropic Crystalline Materials. Angew. Chem. Int. Ed. 2001, 40, 4635-4638. [CrossRef]

3. Pasini, D.; Ricci, M. Macrocycles as Precursors for Organic Nanotubes. Curr. Org. Synth. 2007, 4, 59-80. [CrossRef]

4. Baillargeon, P.; Bernard, S.; Gauthier, D.; Skouta, R.; Dory, Y.L. Efficient Synthesis and Astonishing Supramolecular Architectures of Several Symmetric Macrolactams. Chem. Eur. J. 2007, 13, 9223-9235. [CrossRef] [PubMed]

5. Glaser, R. Polar Order by Rational Design: Crystal Engineering with Parallel Beloamphiphile Monolayers. Acc. Chem. Res. 2007, 40, 9-17. [CrossRef] [PubMed]

6. George, S.; Nangia, A.; Bagieu-Beucher, M.; Masse, R.; Nicoud, J.-F. Crystal engineering of two-dimensional polar layer structures: Hydrogen bond networks in some $N$-meta-phenylpyrimidinones. New J. Chem. 2003, 27, 568-576. [CrossRef]

7. Stone, A.J.; Tsuzuki, S. Intermolecular Interactions in Strongly Polar Crystals with Layer Structures. J. Phys. Chem. B 1997, 101, 10178-10183. [CrossRef]

8. Govindaraju, T.; Avinash, M.B. Two-dimensional nanoarchitectonics: Organic and hybrid materials. Nanoscale 2012, 4, 6102-6117. [CrossRef] [PubMed]

9. Palmore, G.T.R.; McBride, M.T. Engineering layers in molecular solids with the cyclic dipeptide of (S)-aspartic acid. Chem. Commun. 1998, 145-146. [CrossRef]

10. Hosseini, M.W. Molecular Tectonics: From Simple Tectons to Complex Molecular Networks. Acc. Chem. Res. 2005, 38, 313-323. [CrossRef] [PubMed] 
11. Wuest, J.D. Engineering crystals by the strategy of molecular tectonics. Chem. Commun. 2005, 5830-5837. [CrossRef] [PubMed]

12. Baillargeon, P.; Fortin, D.; Dory, Y.L. Hierarchical Self-Assembly of Lactams into Supramolecular CO-Spiked "Sea Urchins" and Then into a Channeled Crystal. Cryst. Growth Des. 2010, 10, 4357-4362. [CrossRef]

13. Gordon, M.S.; Jensen, J.H. Understanding the Hydrogen Bond Using Quantum Chemistry. Acc. Chem. Res. 1996, 29, 536-543. [CrossRef]

14. Steiner, T. The Hydrogen Bond in the Solid State. Angew. Chem. Int. Ed. 2002, 41, 48-76. [CrossRef]

15. Taylor, R.; Kennard, O. Hydrogen-Bond Geometry in Organic Crystals. Acc. Chem. Res. 1984, 17, $320-326$. [CrossRef]

16. Desiraju, G.R. The C-H…O Hydrogen Bond: Structural Implications and Supramolecular Design. Acc. Chem. Res. 1996, 29, 411-449. [CrossRef] [PubMed]

17. Bella, J.; Humphries, M.J. C $\alpha-\mathrm{H} \cdots \mathrm{O}=\mathrm{C}$ hydrogen bonds contribute to the specificity of RGD cell-adhesion interactions. BMC Struct. Biol. 2005, 5. [CrossRef] [PubMed]

18. Pierce, A.C.; Sandretto, K.L.; Bemis, G.W. Kinase Inhibitors and the Case for CH...O Hydrogen Bonds in Protein-Ligand Binding. Proteins 2002, 49, 567-576. [CrossRef] [PubMed]

19. Weiss, M.S.; Brandl, M.; Sühnel, J.; Pal, D.; Hilgenfeld, R. More hydrogen bonds for the (structural) biologist. Trends Biochem. Sci. 2001, 26, 521-523. [CrossRef]

20. Steiner, T.; Desiraju, G.R. Distinction between the weak hydrogen bond and the van der Waals interaction. Chem. Commun. 1998, 891-892. [CrossRef]

21. Desiraju, G.R. Hydrogen Bridges in Crystal Engineering: Interactions without Borders. Acc. Chem. Res. 2002, 35, 565-573. [CrossRef] [PubMed]

22. Perlstein, J.; Steppe, K.; Vaday, S.; Ndip, E.M.N. Molecular Self-Assemblies. 5. Analysis of the Vector Properties of Hydrogen Bonding in Crystal Engineering. J. Am. Chem. Soc. 1996, 118, 8433-8443. [CrossRef]

23. Ji, W.; Liu, G.; Li, Z.; Feng, C. Influence of C-H..O Hydrogen Bonds on Macroscopic Properties of Supramolecular Assembly. ACS Appl. Mater. Interfaces 2016, 8, 5188-5195. [CrossRef] [PubMed]

24. Metrangolo, P.; Neukirch, H.; Pilati, T.; Resnati, G. Halogen Bonding Based Recognition Processes: A World Parallel to Hydrogen Bonding. Acc. Chem. Res. 2005, 38, 386-395. [CrossRef] [PubMed]

25. Legon, A.C. Prereactive Complexes of Dihalogens XY with Lewis Bases B in the Gas Phase: A Systematic Case for the Halogen Analogue B..XY of the Hydrogen Bond B..HX. Angew. Chem. Int. Ed. 1999, 38, 2686-2714. [CrossRef]

26. Auffinger, P.; Hays, F.A.; Westhof, E.; Ho, P.S. Halogen bonds in biological molecules. Proc. Natl. Acad. Sci. USA 2004, 101, 16789-16794. [CrossRef] [PubMed]

27. Awwadi, F.F.; Willett, R.D.; Peterson, K.A.; Twamley, B. The Nature of Halogen $\cdots$ Halogen Synthons: Crystallographic and Theoretical Studies. Chem. Eur. J. 2006, 12, 8952-8960. [CrossRef] [PubMed]

28. Metrangolo, P.; Pilati, T.; Resnati, G. Halogen bonding and other noncovalent interactions involving halogens: A terminology issue. CrystEngComm 2006, 8, 946-947. [CrossRef]

29. Dey, A.; Jetti, R.K.R.; Boese, R.; Desiraju, G.R. Supramolecular equivalence of halogen, ethynyl and hydroxy groups. A comparison of the crystal structures of some 4-substituted anilines. CrystEngComm 2003, 5, 248-252. [CrossRef]

30. Metrangolo, P.; Resnati, G.; Pilati, T.; Liantonio, R.; Meyer, F. Engineering Functional Materials by Halogen Bonding. J. Polym. Sci. A Polym. Chem. 2007, 45, 1-15. [CrossRef]

31. Gilday, L.C.; Robinson, S.W.; Barendt, T.A.; Langton, M.J.; Mullaney, B.R.; Beer, P.D. Halogen Bonding in Supramolecular Chemistry. Chem. Rev. 2015, 115, 7118-7195. [CrossRef] [PubMed]

32. Mukherjee, A.; Tothadi, S.; Desiraju, G.R. Halogen Bonds in Crystal Engineering: Like Hydrogen Bonds yet Different. Acc. Chem. Res. 2014, 47, 2514-2524. [CrossRef] [PubMed]

33. Politzer, P.; Murray, J.S.; Janjić, G.V.; Zarić, S.D. $\sigma$-Hole Interactions of Covalently-Bonded Nitrogen, Phosphorus and Arsenic: A Survey of Crystal Structures. Crystals 2014, 4, 12-31. [CrossRef]

34. Aakeröy, C.B.; Baldrighi, M.; Desper, J.; Metrangolo, P.; Resnati, G. Supramolecular Hierarchy among Halogen-Bond Donors. Chem. Eur. J. 2013, 19, 16240-16247. [CrossRef] [PubMed]

35. Lieffrig, J.; Jeannin, O.; Frackowiak, A.; Olejniczak, I.; Swietlik, R.; Dahaoui, S.; Aubert, E.; Espinosa, E.; Auban-Senzier, P.; Fourmigué, M. Charge-Assisted Halogen Bonding: Donor-Acceptor Complexes with Variable Ionicity. Chem. Eur. J. 2013, 19, 14804-14813. [CrossRef] [PubMed] 
36. Cavallo, G.; Metrangolo, P.; Milani, R.; Pilati, T.; Priimagi, A.; Resnati, G.; Terraneo, G. The Halogen Bond. Chem. Rev. 2016, 116, 2478-2601. [CrossRef] [PubMed]

37. Baillargeon, P.; Dory, Y.L. Supramolecular Walls from Cyclic Peptides: Modulating Nature and Strength of Weak Interactions. Cryst. Growth Des. 2009, 9, 3638-3645. [CrossRef]

38. Baillargeon, P.; Lussier, T.; Dory, Y.L. Hydrogen Bonds between Acidic Protons from Alkynes (C-H...O) and Amides (N-H...O) and Carbonyl Oxygen Atoms as Acceptor Partners. J. Crystallogr. 2014, 2014, 1-5. [CrossRef]

39. SeethaLekshmi, S.; Varughese, S.; Girl, L.; Pedireddi, V.R. Molecular Complexes of 4-Halophenylboronic Acids: A Systematic Exploration of Isostructurality and Structural Landscape. Cryst. Growth Des. 2014, 14, 4143-4154. [CrossRef]

40. Dechambenoit, P.; Ferlay, S.; Kyritsakas, N.; Hosseini, M.W. Playing with isostructurality: From tectons to molecular alloys and composite crystals. Chem. Commun. 2009, 1559-1561. [CrossRef] [PubMed]

41. Aakeröy, C.B.; Schultheiss, N.C.; Rajbanshi, A.; Desper, J.; Moore, C. Supramolecular Synthesis Based on a Combination of Hydrogen and Halogen Bonds. Cryst. Growth Des. 2009, 9, 432-441. [CrossRef] [PubMed]

42. Ebenezer, S.; Muthiah, P.T.; Butcher, R.J. Design of a Series of Isostructural Co-Crystals with Aminopyrimidines: Isostructurality through Chloro/Methyl Exchange and Studies on Supramolecular Architectures. Cryst. Growth Des. 2011, 11, 3579-3592. [CrossRef]

43. Ekkebus, R.; van Kasteren, S.I.; Kulathu, Y.; Scholten, A.; Berlin, I.; Geurink, P.P.; de Jong, A.; Goerdayal, S.; Neefjes, J.; Heck, A.J.R.; et al. On Terminal Alkynes that Can React with Active-Site Cysteine Nucleophiles in Proteases. J. Am. Chem. Soc. 2013, 135, 2867-2870. [CrossRef] [PubMed]

44. Sommer, S.; Weikart, N.D.; Linne, U.; Mootz, H.D. Covalent inhibition of SUMO and ubiquitin-specific cysteine proteases by an in situ thiol-alkyne addition. Bioorg. Med. Chem. 2013, 21, 2511-2517. [CrossRef] [PubMed]

45. Wu, W.; Jiang, H. Haloalkynes: A Powerful and Versatile Building Block in Organic Synthesis. Acc. Chem. Res. 2014, 47, 2483-2504. [CrossRef] [PubMed]

46. Mevers, E.; Liu, W.-T.; Engene, N.; Mohimani, H.; Byrum, T.; Pevzner, P.A.; Dorrestein, P.C.; Spadafora, C.; Gerwick, W.H. Cytotoxic Veraguamides, Alkynyl Bromide-Containing Cyclic Depsipeptides from the Marine Cyanobacterium $c f$. Oscillatoria margaritifera. J. Nat. Prod. 2011, 74, 928-936. [CrossRef] [PubMed]

47. Salvador, L.A.; Biggs, J.S.; Paul, V.J.; Luesch, H. Veraguamides A-G, Cyclic Hexadepsipeptides from a Dolastatin 16-Producing Cyanobacterium Symploca cf. hydnoides from Guam. J. Nat. Prod. 2011, 74, 917-927. [CrossRef] [PubMed]

48. Hay, A.S. Oxidative Coupling of Acetylenes II. J. Org. Chem. 1962, 27, 3320-3321. [CrossRef]

49. Alkorta, I.; Rozas, I.; Elguero, J. Non-conventional hydrogen bonds. Chem. Soc. Rev. 1998, 27, $163-170$. [CrossRef]

50. Hassel, O. Structural Aspects of Interatomic Charge-Transfer Bonding. Science 1970, 170, 497-502. [CrossRef] [PubMed]

51. Bolton, O.; Lee, K.; Kim, H.-J.; Lin, K.Y.; Kim, J. Activating efficient phosphorescence from purely organic materials by crystal design. Nat. Chem. 2011, 3, 205-210. [CrossRef] [PubMed]

52. Metrangolo, P.; Resnati, G. Halogen Bonding: A Paradigm in Supramolecular Chemistry. Chem. Eur. J. 2001, 7, 2511-2519. [CrossRef]

53. Priimagi, A.; Cavallo, G.; Metrangolo, P.; Restani, R. The Halogen Bond in the Design of Functional Supramolecular Materials: Recent Advances. Acc. Chem. Res. 2013, 2686-2695. [CrossRef] [PubMed]

54. Cody, V.; Murray-Rust, P. Iodine $\cdots X(\mathrm{O}, \mathrm{N}, \mathrm{S})$ intermolecular contacts: Models of thyroid hormone protein binding interactions using information from the cambridge crystallographic data files. J. Mol. Struct. 1984, 112, 189-199. [CrossRef]

55. Ouvrard, C.; le Questel, J.-Y.; Berthelot, M.; Laurence, C. Halogen-bond geometry: A crystallographic data-base investigation of dihalogen complexes. Acta Crystallogr. B 2003, 59, 512-526. [CrossRef] [PubMed]

56. Lommerse, J.P.M.; Stone, A.J.; Taylor, R.; Allen, F.H. The Nature and Geometry of Intermolecular Interactions between Halogens and Oxygen or Nitrogen. J. Am. Chem. Soc. 1996, 118, 3108-3116. [CrossRef]

57. Hoheisel, T.N.; Schrettl, S.; Marty, R.; Todorova, T.K.; Corminboeuf, C.; Sienkiewicz, A. A multistep single-crystal-to-single-crystal bromodiacetylene dimerization. Nat. Chem. 2013, 5, 327-334. [CrossRef] [PubMed] 
58. Curtis, S.M.; Le, N.; Nguyen, T.; Ouyang, X.; Tran, T.; Fowler, F.W.; Lauher, J.W. What have We Learned about Topochemical Diacetylene Polymerizations? Supramol. Chem. 2005, 17, 31-36. [CrossRef]

59. Okuno, T.; Yamane, K.; Sandman, D.J. Solid State Polymerization of Diacetylenes with Amide Groups. Mol. Cryst. Liq. Cryst. 2006, 456, 45-53. [CrossRef]

60. Luo, L.; Wilhelm, C.; Sun, A.; Grey, C.P.; Lauher, J.W.; Goroff, N.S. Poly(diiododiacetylene): Preparation, isolation, and full characterization of a very simple poly(diacetylene). J. Am. Chem. Soc. 2008, 130, 7702-7709. [CrossRef] [PubMed]

61. Li, Z.; Fowler, F.W.; Lauher, J.W. Weak Interactions Dominating the Supramolecular Self-Assembly in a Salt: A Designed Single-Crystal-to-Single-Crystal Topochemical Polymerization of a Terminal Aryldiacetylene. J. Am. Chem. Soc. 2009, 131, 634-643. [CrossRef] [PubMed]

62. Jin, H.; Plonka, A.M.; Parise, J.B.; Goroff, N.S. Pressure induced topochemical polymerization of diiodobutadiyne: A single-crystal-to-single-crystal transformation. CrystEngComm 2013, 15, 3106-3110. [CrossRef]

63. Haridas, V.; Sadanandan, S.; Collart-Dutilleul, P.-Y.; Gronthos, S.; Voelcker, N.H. Lysine-Appended Polydiacetylene Scaffolds for Human Mesenchymal Stem Cells. Biomacromolecules 2014, 15, 582-590. [CrossRef] [PubMed]

64. Xu, W.L.; Smith, M.D.; Krause, J.A.; Greytak, A.B.; Ma, S.; Read, C.M.; Shimizu, L.S. Single Crystal to Single Crystal Polymerization of a Self-Assembled Diacetylene Macrocycle Affords Columnar Polydiacetylenes. Cryst. Growth Des. 2014, 14, 993-1002. [CrossRef]

65. Wang, S.; Li, Y.; Liu, H.; Li, J.; Li, T.; Wu, Y.; Okada, S.; Nakanishi, H. Topochemical polymerization of unsymmetrical aryldiacetylene supramolecules with nitrophenyl substituents utilizing $\mathrm{C}-\mathrm{H} \cdots \pi$ interactions. Org. Biomol. Chem. 2015, 13, 5467-5474. [CrossRef] [PubMed]

66. Lauher, J.W.; Fowler, F.W. Single-Crystal-to-Single-Crystal Topochemical Polymerizations by Design. Acc. Chem. Res. 2008, 41, 1215-1229. [CrossRef] [PubMed]

67. Jelinek, R.; Ritenberg, M. Polydiacetylenes-Recent molecular advances and applications. RSC Adv. 2013, 3, 21192-21201. [CrossRef]

68. Kohn, W.; Sham, L. Self-Consistent Equations Including Exchange and Correlation Effects. J. Phys. Rev. 1965, 140, A1133-A1138. [CrossRef]

69. Becke, A.D. Perspective: Fifty years of density-functional theory in chemical physics. J. Phys. Chem. 2014, 140, 18A301. [CrossRef] [PubMed]

70. Rezác, J.; Hobza, P. Benchmark Calculations of Interaction Energies in Noncovalent Complexes and Their Applications. Chem. Rev. 2016. [CrossRef]

71. Kolář, M.H.; Hobza, P. Computer Modeling of Halogen Bonds and Other $\sigma$-Hole Interactions. Chem. Rev. 2016. [CrossRef]

72. Feldblum, E.S.; Arkin, I.T. Strength of a bifurcated H bond. Proc. Natl. Acad. Sci. 2014, 111, 4085-4090. [CrossRef] [PubMed]

73. Adalsteinsson, H.; Maulitz, A.H.; Bruice, T.C. Calculation of the Potential Energy Surface for Intermolecular Amide Hydrogen Bonds Using Semiempirical and Ab Initio Methods. J. Am. Chem. Soc. 1996, 118, 7689-7693. [CrossRef]

74. Li, A.; Muddana, H.S.; Gilson, M.K. Quantum Mechanical Calculation of Noncovalent Interactions: A Large-Scale Evaluation of PMx, DFT, and SAPT Approaches. J. Chem. Theory Comput. 2014, 10, 1563-1575. [CrossRef] [PubMed]

75. Zhao, Y.; Truhlar, D.G. Density Functionals with Broad Applicability in Chemistry. Acc. Chem. Res. 2008, 41, 157-167. [CrossRef] [PubMed]

76. Ivanova, B.; Spiteller, M. Binding affinity of terrestrial and aquatic humics toward organic xenobiotics. J. Environ. Chem. Eng. 2016, 4, 498-510. [CrossRef]

77. Schmidt, M.W.; Baldridge, K.K.; Boatz, J.A.; Elbert, S.T.; Gordon, M.S.; Jensen, J.H.; Koseki, S.; Matsunaga, N.; Nguyen, K.A.; Su, S.; et al. General Atomic and Molecular Electronic Structure System. J. Comput. Chem. 1993, 14, 1347-1363. [CrossRef]

78. Becke, A.D. Density-functional thermochemistry. III. The role of exact exchange. J. Chem. Phys. 1993, 98, 5648-5652. [CrossRef] 
79. Zhao, Y.; Truhlar, D.G. The M06 suite of density functionals for main group thermochemistry, thermochemical kinetics, noncovalent interactions, excited states, and transition elements: Two new functionals and systematic testing of four M06-class functionals and 12 other function. Theor. Chem. Acc. 2008, 120, 215-241. [CrossRef]

80. Shirman, T.; Boterashvili, M.; Orbach, M.; Freeman, D.; Shimon, L.J.W.; Lahav, M.; van der Boom, M.E. Finding the Perfect Match: Halogen vs. Hydrogen Bonding. Cryst. Growth Des. 2015, 15, 4756-4759. [CrossRef]

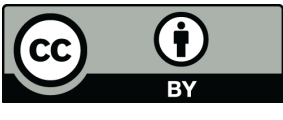

(C) 2016 by the authors; licensee MDPI, Basel, Switzerland. This article is an open access article distributed under the terms and conditions of the Creative Commons by Attribution (CC-BY) license (http://creativecommons.org/licenses/by/4.0/). 